Article

\title{
Neuroprotective Effect of Bergamot Juice in 6-OHDA-Induced SH-SY5Y Cell Death, an In Vitro Model of Parkinson's Disease
}

\author{
Nadia Ferlazzo ${ }^{1,2}$, Santa Cirmi ${ }^{1}{ }^{\circledR}$, Alessandro Maugeri ${ }^{1}$, Caterina Russo ${ }^{1,3}$, \\ Giovanni Enrico Lombardo ${ }^{1}$, Sebastiano Gangemi ${ }^{4}$, Gioacchino Calapai ${ }^{5}$, Vincenzo Mollace ${ }^{2}$ \\ and Michele Navarra $1, *$ (D) \\ 1 Department of Chemical, Biological, Pharmaceutical and Environmental Sciences, University of Messina, \\ 98100 Messina, Italy; nferlazzo@unime.it (N.F.); scirmi@unime.it (S.C.); amaugeri@unime.it (A.M.); \\ cate.russo.22@gmail.com (C.R.); gelombardo@unime.it (G.E.L.) \\ 2 Department of Health Sciences, University “Magna Græcia” of Catanzaro, 88100 Catanzaro, Italy; \\ mollace@unicz.it \\ 3 Fondazione "Prof. Antonio Imbesi", 98100 Messina, Italy \\ 4 Department of Clinical and Experimental Medicine, University of Messina, 98100 Messina, Italy; \\ gangemis@unime.it \\ 5 Department of Biomedical and Dental Sciences and Morphofunctional Imaging, University of Messina, \\ 98100 Messina, Italy; gcalapai@unime.it \\ * Correspondence: mnavarra@unime.it
}

Received: 3 March 2020; Accepted: 3 April 2020; Published: 5 April 2020

\begin{abstract}
Much evidence suggests that both oxidative stress and apoptosis play a key role in the pathogenesis of Parkinson's disease (PD). The present study aims to evaluate the protective effect of bergamot juice (BJ) against 6-hydroxydopamine (6-OHDA)- or $\mathrm{H}_{2} \mathrm{O}_{2}$-induced cell death. Treatment of differentiated SH-SY5Y human neuroblastoma cells with 6-OHDA or $\mathrm{H}_{2} \mathrm{O}_{2}$ resulted in cell death that was significantly reduced by the pre-treatment with BJ. The protective effects of $\mathrm{BJ}$ seem to correlate with the reduction of intracellular reactive oxygen species and nitric oxide generation caused by 6-OHDA or $\mathrm{H}_{2} \mathrm{O}_{2}$. BJ also attenuated mitochondrial dysfunction, caspase-3 activation, imbalance of pro- and anti-apoptotic proteins, MAPKs activation and reduced NF-kB nuclear translocation evoked by neurotoxic agents. Additionally, BJ exhibited excellent antioxidant capability in cell-free assays. Collectively, our results suggest that BJ exerts neuroprotective effect through the interplay with specific cell targets and its antioxidant activity, making it worthy of consideration for the management of neurodegenerative diseases.
\end{abstract}

Keywords: Citrus bergamia; Parkinson's disease; SH-SY5Y cells; natural products; 6-OHDA; bergamot

\section{Introduction}

Parkinson's disease (PD) is a progressive disorder of nervous system, affecting two to three percent of the population over 65 years old. Thus, PD represents the second-most common neurodegenerative illness with more than six million cases worldwide. It is defined by an incremental impairment of dopaminergic neurons localized in the substantia nigra, which is implied in motor control and reward. Although the true etiology of PD is yet under debate, several molecular events have been identified so far as important intermediaries of neuronal cell death, including oxidative/nitrosative stress, activation of neuroinflammatory processes, mitochondrial dysfunction and apoptotic cascade [1,2]. At present, no drug has been proved to exert clinically validated neuroprotective effect, showing their efficacy just on symptoms [3], so that development of more effective pharmacological strategies is highly 
desirable. Comprehensive research on novel neuroprotective drugs has proven that anti-inflammatory and antioxidant molecules from dietary sources may prevent and/or counteract neurodegenerative diseases, such as PD [4,5]. In this regard, nutraceuticals and food supplements have been shown to provide neuroprotection in several experimental models, and their use, as alternative to synthetic drugs or in combination with these, is justified by their capability of abolishing or, at least, mitigating the unwanted side effects of established therapies [5-7].

Citrus bergamia Risso et Poiteau (bergamot) is a small tree of the Rutaceae family, almost solely cultivated for its fruit, from which is extracted an essential oil widely used in the fragrance industry. However, it has been recently proposed that the bergamot essential oil (BEO) can exert benefits on health [8,9] thanks to its anti-infective [10], anti-cancer [11] and neuroprotective [12] effects. Instead, bergamot juice (BJ) was considered a byproduct until last decade, when its pharmacological activities have been described [13-15]. Many of those are due to its flavonoids, the most common polyphenolic compounds of human diet. Given the promising biologic activities of flavonoids [16-19], there is a great interest in their potential neuroprotective effect [20]. On this issue, several studies have suggested that Citrus flavonoids can prevent neurodegeneration, as well as other age-related conditions, and promote brain functions [7,21]. Evidence that the most representative flavonoids of Citrus fruit, including hesperidin, hesperetin and naringenin, can cross the brain-blood barrier [22], reinforces this assumption.

The 6-hydroxydopamine (6-OHDA) is a neurotoxin largely employed to reproduce experimental models of PD [23]. Its auto-oxidative metabolites cause cytotoxicity in various cell lines, including neuroblastoma cells [23], by generating hydrogen peroxide $\left(\mathrm{H}_{2} \mathrm{O}_{2}\right)$, superoxide anion and hydroxyl radicals that, together with other reactive oxygen species (ROS), determine loss of mitochondrial membrane permeability, thus leading to the generation of oxidative stress. The mitochondrial impairment provokes release of cytochrome $c$ and other pro-apoptotic proteins that activate downstream effectors such as caspase-3 that causes neuronal cell death.

On this basis, we investigated whether BJ protects differentiated SH-SY5Y cells from 6-OHDA- or $\mathrm{H}_{2} \mathrm{O}_{2}$-induced neurotoxicity, exploring its mechanism of action. This could give indications on the neuroprotective potential of $\mathrm{BJ}$.

\section{Materials and Methods}

\subsection{Drug}

Citrus bergamia fruits were harvested in Bovalino (Reggio Calabria, Italy). Afterwards, they were hand-squeezed, and aliquots of juice were kept at $-20{ }^{\circ} \mathrm{C}$. For the experiments on cell cultures, the $\mathrm{pH}$ of BJ was arranged to 7.4, filtered and diluted in culture media to reach required concentrations prior to use. The chemical characterization of flavonoids present in BJ has been reported previously [24-26]. However, before starting this study, a qualitative and quantitative HPLC analysis was performed, confirming that the flavonoids composition corresponds to those already published [24,26]. Naringin, hesperetin, neohesperidin and neoeriocitrin are the most abundant flavonoids in the BJ tested in these studies.

\subsection{Abiotic Assay}

The antioxidant activity of BJ was assessed through the stable 2,2-diphenylpicrylhydrazyl (DPPH) radical assay, the reducing power determination and the oxygen radical absorbance capacity (ORAC) assay. Total phenolic content of BJ was measured through the Folin-Ciocalteu assay. All cell-free tests were performed following the procedure employed by Ferlazzo et al. [27].

\subsection{Cell Culture}

Experiments were carried out using the SH-SY5Y human neuroblastoma cell line (originally from ATCC, Rockville, MD, USA). Cells were differentiated in MEM/Ham's F12 medium supplemented with 
10- $\mu \mathrm{M}$ retinoic acid (RA; Sigma-Aldrich, Milan, Italy) for 5 days as reported by Condello et al. [28]. All reagents were from Gibco (Life Technologies, Monza, Italy).

\subsection{Cytotoxicity Assay}

Cell viability was assessed by the 1-(4,5-dimethylthiazol-2-yl)-3,5-diphenylformazan (MTT) test as reported [29]. The cells were plated into 96-well plates $\left(5 \times 10^{4}\right.$ cells/well $)$ and $24 \mathrm{~h}$ later were treated with BJ $0.5 \%$ or $1 \%$ for $1 \mathrm{~h}$. Then, 6-OHDA (50 or $100 \mu \mathrm{M}$; Sigma-Aldrich) or $\mathrm{H}_{2} \mathrm{O}_{2}(50-150 \mu \mathrm{M}$; Sigma-Aldrich) were added for additional $24 \mathrm{~h}$. The absorbance was recorded at $570 \mathrm{~nm}$ (reference at $690 \mathrm{~nm}$ ) by a microplate spectrophotometer.

Cell death was assessed by the trypan blue $(0.4 \% w / v ; \mathrm{TB})$ exclusion test. Cells were seeded onto 6-well plates at a density of $10 \times 10^{3}$ cells/well for $24 \mathrm{~h}$, and then treated with BJ $0.5 \%$ or $1 \%$ for $1 \mathrm{~h}$ prior to be incubated with either 6-OHDA $(50$ or $100 \mu \mathrm{M})$ or $\mathrm{H}_{2} \mathrm{O}_{2}(50$ or $100 \mu \mathrm{M})$ for further $24 \mathrm{~h}$. Then, cells were trypsinized, centrifuged, re-suspended in a known volume of PBS and stained with the trypan blue dye, before proceeding with cell count [30,31].

\subsection{Detection of Apoptosis by Annexin-V FITC Staining}

AnnexinV/PI staining was employed to discriminate cells among living, apoptotic and necrotic. Cells were seeded in 6-well plates at a density of $5 \times 10^{5}$ cells/well and left for $24 \mathrm{~h}$. Afterward, the cultures were pre-treated for $1 \mathrm{~h}$ with $\mathrm{BJ}(0.5 \%$ and $1 \%)$, and then exposed to 50- $\mu \mathrm{M}$ 6-OHDA. After $24 \mathrm{~h}$ of incubation, the cells were processed as reported [19]. Finally, specimens were run on NovoCyte Flow Cytometer Systems (ACEA Biosciences Inc., San Diego, CA, USA).

\subsection{Spectrofluorimetric Determination of ROS and $\Delta \psi m$}

As oxidative stress biomarkers, ROS and mitochondrial membrane potential $(\Delta \psi \mathrm{m})$ were measured by fluorometric methods. In both assays, the cells were seeded onto 96 -well plates $\left(5 \times 10^{4}\right.$ cells/well), and the following day, they were pre-treated with $\mathrm{BJ}(0.5 \%$ and $1 \%)$ for $1 \mathrm{~h}$ and then exposed to 6-OHDA $(50 \mu \mathrm{M})$ or $\mathrm{H}_{2} \mathrm{O}_{2}(100 \mu \mathrm{M})$ for additional $6 \mathrm{~h}$.

ROS were quantified using $2^{\prime}, 7^{\prime}$-dichlorodihydrofluorescein diacetate (DCFH-DA $25 \mu \mathrm{M}$; Sigma-Aldrich) as reported [12]. The fluorescence was recorded by a microplate reader (POLARstar Omega, BMG Labtech, Ortenberg, Germany) at $485 \mathrm{~nm}$ excitation and $535 \mathrm{~nm}$ emission.

Changes in $\Delta \psi \mathrm{m}$ were estimated by measuring Rhodamine 123 incorporation (R123; Sigma-Aldrich), as reported by Condello et al. [28]. The intensity of fluorescence was recorded at $488 \mathrm{~nm}$ excitation and $525 \mathrm{~nm}$ emission.

\subsection{Caspase-3 Enzymatic Activity}

Caspase enzyme activity was measured using a commercial kit (AbCam, Cambridge, UK). SH-SY5Y cells were differentiated in $100 \mathrm{~mm}$ petri dishes $\left(1.5 \times 10^{6}\right.$ cells $)$, and then treated with $0.5 \%$ or $1 \% \mathrm{BJ}$ for $1 \mathrm{~h}$, prior to be incubated with 50- $\mu \mathrm{M}$ 6-OHDA for $6 \mathrm{~h}$. Then, according to the manufacturer's instructions, cells were lysed, centrifuged and on the supernatant was carried out the analysis. The absorbance was measured at a wavelength of $405 \mathrm{~nm}$ by a microplate spectrophotometer.

\subsection{Western Blot}

SH-SY5Y cells $\left(1.5 \times 10^{6}\right.$ cells) were differentiated, pre-treated with $0.5 \%$ or $1 \%$ BJ for $1 \mathrm{~h}$ and then incubated with 50- $\mu \mathrm{M} 6$-OHDA for additional 6 or $24 \mathrm{~h}$. Total cellular lysates were prepared, quantified and electrophoresed ( $30 \mu \mathrm{g} / \mathrm{lane})$ as reported by Celano et al. [32]. The membranes were blocked with $5 \%$ nonfat milk and then incubated overnight at $4{ }^{\circ} \mathrm{C}$ with the following antibodies: rabbit anti-phospho p44/42 MAPK (Thr 202/Try 204) and anti-p44/42 MAPK (Cell Signaling Technology, Beverly, MA, USA); rabbit anti-phospho p38 and rabbit anti-p38 (AbCam); rabbit anti-iNOS and nNOS (Becton Dickinson, Franklin Lakes, NJ, USA); mouse anti-p53 (AbCam); mouse anti-Bax and anti-Bcl-2 (Thermo Fisher 
Scientific, Waltham, MA, USA); rabbit anti- $\beta$-actin (Cell Signaling Technology). Secondary goat HRP-conjugated anti-mouse or anti-rabbit IgG antibody (AbCam) were incubated at room temperature for $2 \mathrm{~h}$. A representative immunoblot image of three independent experiments for each target is shown. Autoradiographic bands were quantified by ImageJ software and normalized for $\beta$-actin levels.

\subsection{Evaluation of NF-kB Activation}

The presence of NF-kB DNA binding activity was assessed by a gel electromobility shift assay (EMSA) kit (Panomics, Inc., Fremont, CA, USA) [25,33]. To this aim SH-SY5Y were seeded in $100 \mathrm{~mm}$ Petri dishes $\left(1.5 \times 10^{6}\right.$ cells) and differentiated as above described. The cells were treated with BJ $0.5 \%$ or $1 \%$ for $24 \mathrm{~h}$, and then incubated with 50- $\mu \mathrm{M}$ 6-OHDA for $6 \mathrm{~h}$. Afterwards, the nuclear proteins were extracted from cold PBS washed cells using a commercial kit for nuclear extraction (Panomics), observing manufacturer's guidelines. First, protein amounts were determined employing a protein assay commercial kit (Bio-Rad Laboratory, Hercules, CA, USA). Then, DNA-protein binding reaction was carried out in supplied binding buffer containing $1 \mu \mathrm{L}$ of probe (NF- $\mathrm{KB} 5^{\prime}$ AGTTGAGGGGACTTTCCCAGGC $\left.3^{\prime}\right), 4 \mu \mathrm{g}$ of nuclear extracts and $1 \mu \mathrm{L}$ poly(dI-DC) at $15^{\circ} \mathrm{C}$ for $30 \mathrm{~min}$. After resolving complexes on a $6 \%$ non-denaturing acrylamide gel, these were transferred onto positively charged nylon membranes, and cross-linked at $120 \mathrm{~mJ} / \mathrm{cm}^{2}$ for $1 \mathrm{~min}$ using a UV-light cross-link instrument (UV Stratalinker 1800, Stratagene, San Diego, CA, USA). DNA-protein binding was detected using streptavidin-labeled horseradish peroxidase (HRP) conjugate with a chemiluminescent detection system.

\subsection{Determination of NO Accumulation in SH-SY5Yculture Supernatant}

Nitric oxide (NO) production was assayed by a colorimetric kit (Sigma-Aldrich). In a 6-well plate $\left(5 \times 10^{5}\right.$ cells/well $)$ the differentiated cells were pre-incubated with BJ for $1 \mathrm{~h}$, and then treated with $50-\mu \mathrm{M} 6-\mathrm{OHDA}$ for $24 \mathrm{~h}$. The supernatants were collected and processed following manufacturer's guidelines. Absorbance was spectrophotometrically quantified at a wavelength of $540 \mathrm{~nm}$ by a microplate spectrophotometer.

\subsection{Statistical Analyses}

One-way analysis of variance (ANOVA) was employed to analyze data. Multiple comparisons of the means of the groups were performed by the Tukey-Kramer test (GrafPAD Software for Science, version 7.0, Graphpad Software, Inc., San Diego, CA, USA).

\section{Results}

\subsection{Antioxidant Activity of BJ in Abiotic Models}

Both the antioxidant and the radical scavenging properties of BJ have been demonstrated using numerous cell-free tests. The total phenolic amount, evaluated by Folin-Ciocalteu method, was $2.23 \pm 0.04 \mathrm{mg} \mathrm{GAE} / \mathrm{mL}$ of BJ, that, along with the results of the Reducing Power test (Figure 1A), suggested the antioxidant capability of BJ in abiotic models. Both Folin-Ciocalteu and Reducing Power assays are electron/transfer-based tests, performed in high and low $\mathrm{pH}$ values, respectively. In abiotic, low $\mathrm{pH}$ may hinder the activity of antioxidants with a phenolic moiety, due to protonation, while high $\mathrm{pH}$ could cause the opposite, due to dissociation [15]. Consequently, it is reasonable to assess the antioxidant capability of polyphenolic compounds by a series of abiotic tests. BJ also demonstrated a noticeable capability to dampen free radicals in the DPPH test (BJ and dibutylhydroxytoluene (BHT) $\mathrm{IC}_{50}$ was $0.4 \% \pm 0.012$ and $0.8 \% \pm 0.03$, respectively; Figure $1 \mathrm{~B}$ ) and a high ORAC value (4300 $\pm 425 \mu \mathrm{mol} / \mathrm{TE} / \mathrm{L}$ juice) strengthens the results mentioned above. 
A
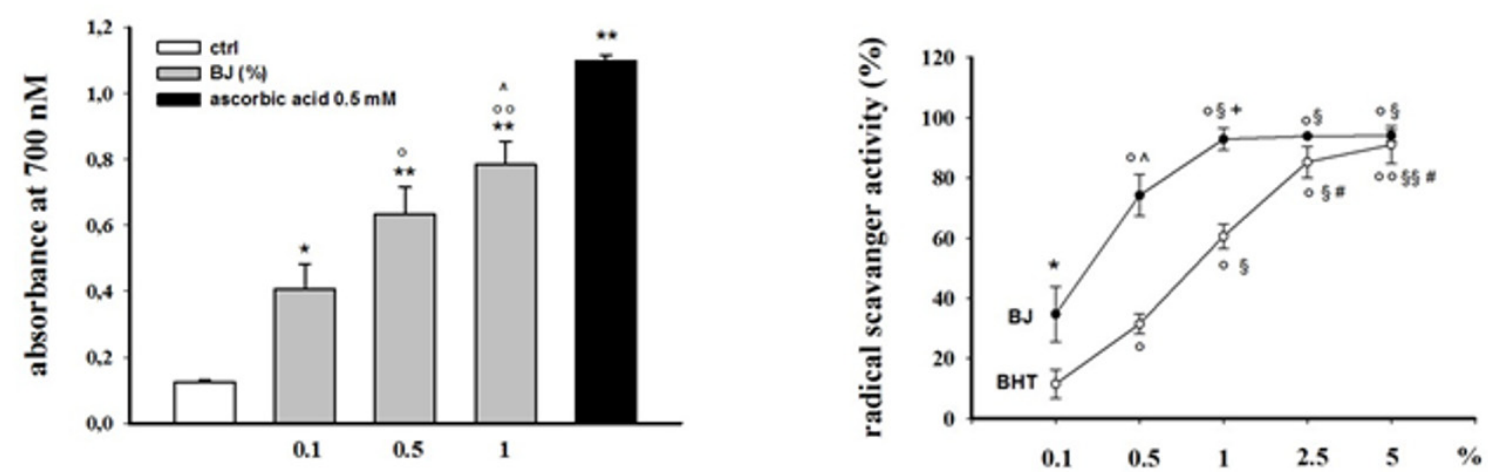

Figure 1. Antioxidant property of bergamot juice (BJ). Evaluation of reducing power (A) and DPPH scavenging activity (B) of BJ. The assays were carried out in triplicate and repeated three times. The results are expressed as mean value \pm S.E.M. Different solutions of ascorbic acid $(0.5 \mathrm{mM} ; \mathbf{A})$ or dibutylhydroxytoluene (BHT) $\left(0.1-5 \% w / v\right.$; B) were used as reference. ${ }^{*} P<0.05$ and ${ }^{* *} P<0.01$ vs. ctrl, ${ }^{\circ} P<0.05$ and ${ }^{\circ} P<0.01$ vs. BJ $0.1 \%,{ }^{\wedge} P<0.05$ vs. BJ $0.5 \%$ (A); ${ }^{\circ} P<0.01$ vs. BJ $0.5 \%$ and BHT $0.5 \%$, ${ }^{\circ} \mathrm{P}<0.001$ vs. BHT $0.5 \%, \S P<0.01$ vs. BJ $0.5 \%$ and BHT $0.5 \%, \S \S P<0.001$ vs. BHT $0.5 \%,{ }^{\#} P<0.001$ vs. BHT $1 \%,{ }^{*} P<0.01$ vs. BHT $0.1 \%,{ }^{\wedge} P<0.01$ vs. BHT $0.5 \%,{ }^{+} P<0.01$ vs. BHT $1 \%$ (B).

\subsection{BJ Prevents 6-OHDA- or $\mathrm{H}_{2} \mathrm{O}_{2}$-Induced SH-SY5Y Cell Death}

With a view to assess the potential neuroprotective capability of $\mathrm{BJ}$, the cells were pre-incubated with BJ $(0.5 \%$ or $1 \%)$ for $1 \mathrm{~h}$ and next exposed to 6-OHDA (50 or $100 \mu \mathrm{M})$ for another $24 \mathrm{~h}$, prior to evaluate the cell viability. As displayed in Figure 2A, when the cells were incubated with the lowest concentration of 6-OHDA, viable cells were $65 \%$ respect to control cells $(P<0.01)$. The pre-treatment with BJ $0.5 \%$ or $1 \%$ significantly restored cell viability up to $78 \%$ and $85 \%$, respectively $(P<0.01$ respect to 6-OHDA-injured cells). The exposure to $100-\mu \mathrm{M}$ 6-OHDA reduced cell viability up to $50 \%(P<0.01)$, whereas the pre-treatment with BJ was able to prevent cell death. Indeed, BJ $0.5 \%$ or $1 \%$ significantly counteracted the cell death evoked by the highest concentration of 6-OHDA up to a $64 \%$ and $72 \%$ of cell viability, respectively ( $P<0.01$ versus 6-OHDA-injured cells; Figure $2 \mathrm{~A})$.

In parallel experiments, the cells were exposed to 50, 100 and $150-\mu \mathrm{M} \mathrm{H}_{2} \mathrm{O}_{2}$ for $24 \mathrm{~h}$, provoking a reduction of cell viability from $20 \%$ to $75 \%\left(P<0.01\right.$ for $50-\mu \mathrm{M} \mathrm{H}_{2} \mathrm{O}_{2}$ and $P<0.001$ for 100 and $150-\mu \mathrm{M}$ $\mathrm{H}_{2} \mathrm{O}_{2}$ versus respective control cells, Figure $2 \mathrm{~B}$ ). The pre-treatment $(1 \mathrm{~h})$ with $\mathrm{BJ} 0.5 \%$ or $1 \%$ prevented cell death evoked by $\mathrm{H}_{2} \mathrm{O}_{2}\left(P<0.05\right.$ and $P<0.001$ versus $\mathrm{H}_{2} \mathrm{O}_{2}$-incubated cells, respectively).

Data of MTT assays are in line with those obtained by the TB tests (Figure 2C,D).

Since 6-OHDA at both $50 \mu \mathrm{M}$ and $100 \mu \mathrm{M}$ was able to significantly reduce cell viability, even though in a slightly different measure, further experiments were carried out using its lowest concentration, while $\mathrm{H}_{2} \mathrm{O}_{2}$ was used at $100-\mu \mathrm{M}$ concentration. 
A

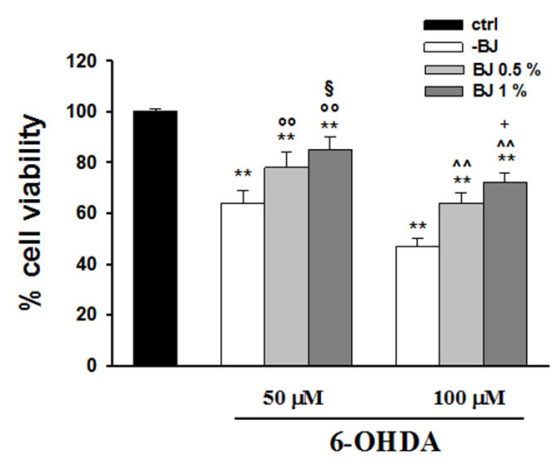

C

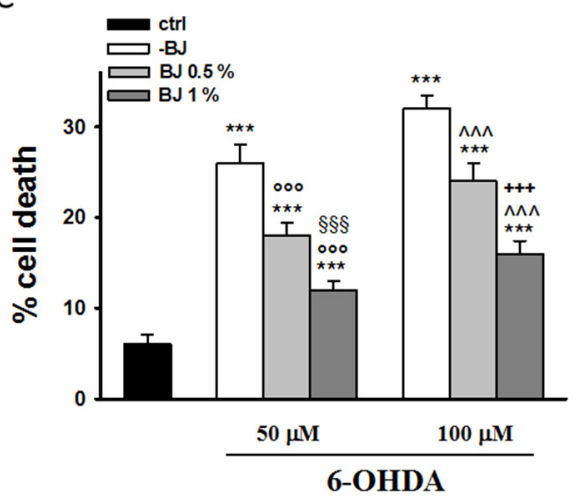

B

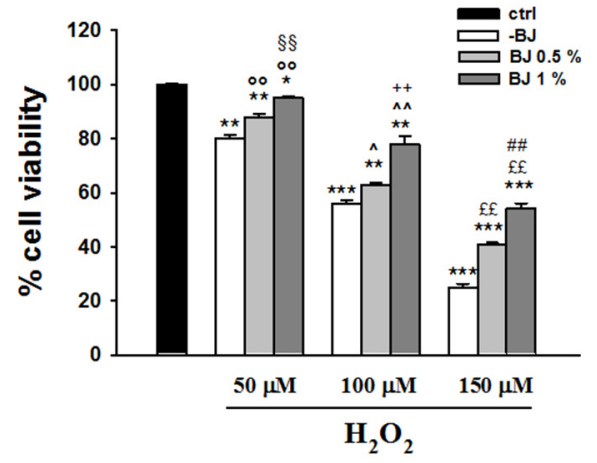

D

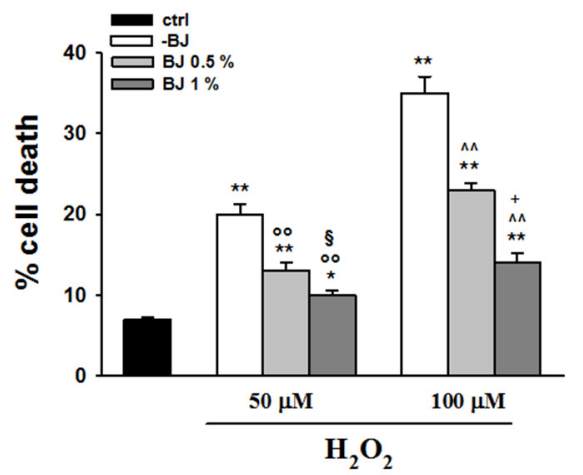

Figure 2. Effect of BJ on cytotoxicity induced by stressors. Cell viability was detected with the 1-(4,5-Dimethylthiazol-2-yl)-3,5-diphenylformazan (MTT) assay (A,B). The change of viability was determined as percentage of viable cells in treated cultures compared to those in untreated ones. Cell death was evaluated by the trypan blue (TB) assay and expressed as percentage of non-viable (blue stained) vs. total cells counted (C,D). Results are showed as means \pm S.E.M. from three independent experiments performed eight-fold (MTT) or in triplicate (TB). ${ }^{*} P<0.05$, ${ }^{* *} P<0.01$ and ${ }^{* * *} P<0.001$ vs. ctrl; ${ }^{\circ \circ} P<0.01$ and ${ }^{\circ \circ \circ} P<0.001$ vs. 6-hydroxydopamine (6-OHDA) or $\mathrm{H}_{2} \mathrm{O}_{2} 50 \mu \mathrm{M}$; ${ }^{\S} P<0.05$,

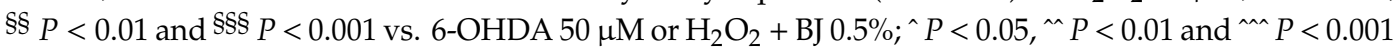
vs. 6-OHDA or $\mathrm{H}_{2} \mathrm{O}_{2} 100 \mu \mathrm{M} ;{ }^{+} P<0.05,{ }^{++} P<0.01$ and ${ }^{+++} P<0.001$ vs. 6-OHDA $100 \mu \mathrm{M}$ or $\mathrm{H}_{2} \mathrm{O}_{2}+\mathrm{BJ} 0.5 \%$; ${ }^{£ f} \mathrm{P}<0.01$ vs. $\mathrm{H}_{2} \mathrm{O}_{2} 150 \mu \mathrm{M}$; ${ }^{\# \#} P<0.01$ vs. $\mathrm{H}_{2} \mathrm{O}_{2} 150 \mu \mathrm{M}+\mathrm{BJ} 0.5 \%$.

3.3. BJ Reduces Intracellular ROS Accumulation and Restores Impaired $\triangle \psi m$ Elicited by 6-OHDA or $\mathrm{H}_{2} \mathrm{O}_{2}$ Exposure

Since the rise of ROS is involved in many pathogenic processes, including PD, we investigated the intracellular ROS level employing the fluorescent probe DCFH-DA. Exposure of SH-SY5Y cells to $50-\mu \mathrm{M} 6-\mathrm{OHDA}$ or $100-\mu \mathrm{M} \mathrm{H}_{2} \mathrm{O}_{2}$ for $6 \mathrm{~h}$ induced a significant intracellular ROS accumulation by 2.2-fold and 3.7-fold, respectively, when compared to the controls ( $P<0.001$; Figure 3A). Pre-treatment with $\mathrm{BJ} 0.5 \%$ and $1 \%$ for $1 \mathrm{~h}$ significantly counteracted 6-OHDA-induced ROS generation of $34(P<0.01)$ and $44 \%(P<0.001)$, respectively (Figure $3 \mathrm{~A})$. In the same manner, $\mathrm{BJ} 0.5 \%$ and $1 \%$, reduced ROS levels in $\mathrm{H}_{2} \mathrm{O}_{2}$-exposed cells by $40 \%$ and $51 \%$, respectively $(P<0.001$; Figure $3 \mathrm{~A})$.

In addition, exposure of SH-SY5Y cells to 50- $\mu \mathrm{M}$ 6-OHDA or 100- $\mu \mathrm{M} \mathrm{H}_{2} \mathrm{O}_{2}$ for $6 \mathrm{~h}$ significantly affected $\Delta \psi \mathrm{m}$, that, in comparison to control cells, decreased by $35 \%$ and $50 \%$, respectively $(P<0.001)$. The reduction of $\Delta \psi \mathrm{m}$ induced by 6 -OHDA or $\mathrm{H}_{2} \mathrm{O}_{2}$ was prevented by both BJ $0.5 \%$ and $1 \%(P<0.05$ and $P<0.01$, respectively; Figure $3 \mathrm{~B}$ ). 
A

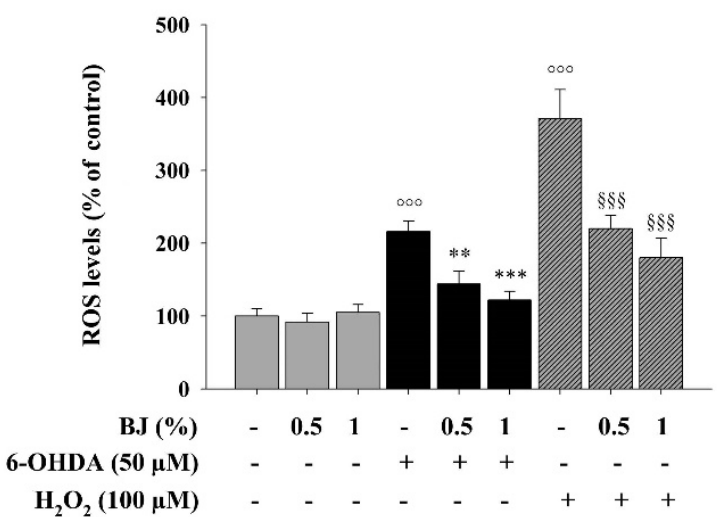

B

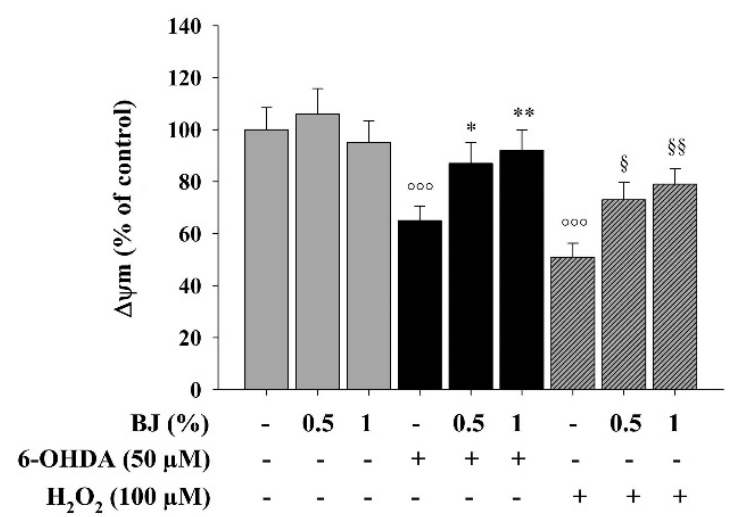

Figure 3. BJ attenuates the accumulation of reactive oxygen species (ROS) and the loss of $\Delta \psi \mathrm{m}$ induced by both 6-OHDA and $\mathrm{H}_{2} \mathrm{O}_{2}$. (A) ROS generation was measured by a fluorescent method, using DCFH-DA as probe. (B) Variations of $\Delta \psi \mathrm{m}$ were assessed using the cationic fluorochrome R123. Results are reported as percentage of the levels detected in untreated cells. Data are shown as the mean \pm S.E.M. of three experiments. ${ }^{\circ 00} P<0.001$ vs. control; ${ }^{*},{ }^{* *}$ and ${ }^{* * *} P<0.05, P<0.01$ and $P<0.001$ vs. 6 -OHDA-treated cells, respectively; $\S, \S \S$ and $\$ \S \S P<0.05, P<0.01$ and $P<0.001$ vs. $\mathrm{H}_{2} \mathrm{O}_{2}$-treated cells, respectively.

\subsection{BJ Reduces the Apoptotic Cell Death Induced by 6-OHDA}

The cytoprotective effect of $\mathrm{BJ}$ was also assessed by cytofluorimetric analysis through the Annexin V fluorescein isothiocyanate (FITC)/propidium iodide (PI) assay. As shown in Figure 4A,B, the incubation of SH-SY5Y cells with 50- $\mu \mathrm{M}$ 6-OHDA for $24 \mathrm{~h}$ increased the percentage of cells in early (37.1\%, AnnexinV+/PI-) and late (13\%, AnnexinV+/PI+) apoptosis. The pre-treatment with BJ reduced the number of cells undergoing apoptosis, with $12.7 \%$ and $7.3 \%$ of early and late apoptosis when the cells where pre-incubated with BJ $0.5 \%$ for $1 \mathrm{~h}$. Similarly, in presence of BJ $1 \%$, the percentage of cells in both early and late apoptosis was of $13.6 \%$ and $5.5 \%$, respectively (Figure $4 \mathrm{~A}, \mathrm{~B}$ ).

The occurrence of apoptosis in 6-OHDA-treated cells was confirmed by the results of the caspase-3 activity assay. The exposure to 50- $\mu \mathrm{M}$ 6-OHDA for $6 \mathrm{~h}$ increased caspase-3 activity of SH-SY5Y cells compared to the unexposed ones $(P<0.001$; Figure $4 \mathrm{C})$. Pre-treatment with BJ $(0.5 \%$ or $1 \% ; 1 \mathrm{~h})$ inhibited the activity of caspase-3 brought by 6-OHDA $(P<0.001)$, while BJ alone had no effect on this enzymatic activity.

Furthermore, compared to control cells, the incubation of SH-SY5Y cells with 50- $\mu \mathrm{M} 6-\mathrm{OHDA}$ for $24 \mathrm{~h}$ significantly enhanced the levels of the pro-apoptotic proteins Bax and p53 up to 1.5- and 1.7-fold $(P<0.001)$, respectively, as well as decreased those of the anti-apoptotic Bcl-2 up to 0.5 -fold $(P<0.01)$. These outcomes were significantly counteracted by the pre-exposure to $\mathrm{BJ}$ at both $0.5 \%$ and $1 \%$ concentrations $(P<0.05$ for Bcl-2, $P<0.01$ for Bax and $P<0.001$ for p53; Figure $5 \mathrm{~A}, \mathrm{~B})$. 
A
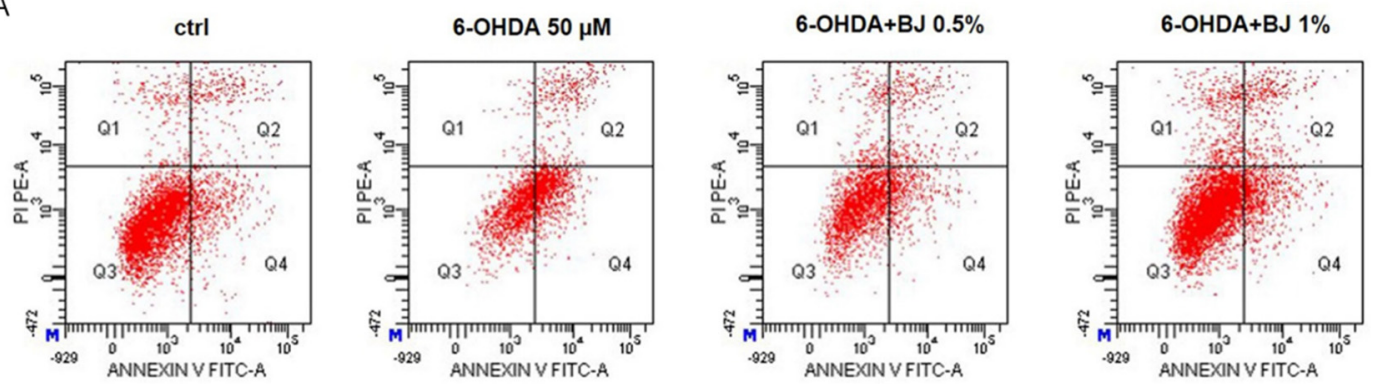

B

\begin{tabular}{|c|c|c|c|c|}
\hline & \multicolumn{4}{|c|}{$\%$} \\
\hline & 01 & $\mathrm{Q} 2$ & $\mathrm{O} 3$ & Q4 \\
\hline ctrl & $1.2 \pm 0.08$ & $2.1 \pm 0.19$ & $90.3 \pm 3.40$ & $6.4 \pm 0.58$ \\
\hline $6-\mathrm{OHDA} 50 \mu \mathrm{M}$ & $1.7 \pm 0.18$ & $13.0 \pm .99^{* *}$ & $48.2 \pm 3.56^{* \prime}$ & $37.1 \pm 1.97^{* \prime}$ \\
\hline $6-\mathrm{OHDA}+\mathrm{BJ} 0.5 \%$ & $9.1 \pm 0.56^{\wedge \wedge}$ & $7.3 \pm 0.62^{\wedge}$ & $70.9 \pm 6.98^{\wedge}$ & $12.7 \pm 1.02^{\wedge}$ \\
\hline $6-\mathrm{OHDA}+\mathrm{BJ} 1 \%$ & $4.8 \pm 0.45^{\wedge \circ}$ & $5.5 \pm 0.51^{1 \mathrm{Ao}^{\circ}}$ & $76.1 \pm 6.89^{\wedge \wedge}$ & $13.6 \pm 0.99^{\wedge}$ \\
\hline
\end{tabular}

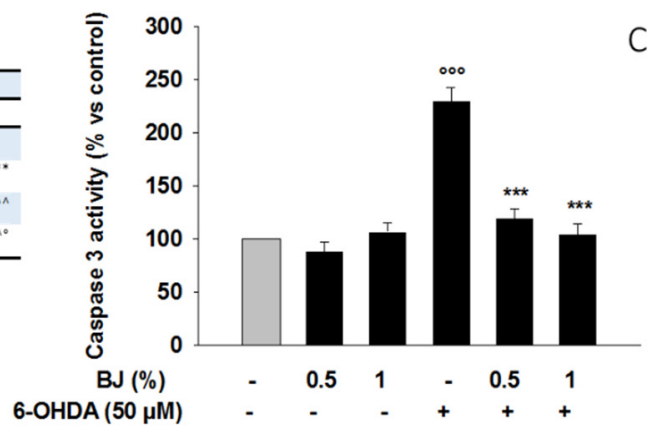

Figure 4. BJ attenuates 6-OHDA-induced apoptosis. (A) Evaluation of apoptosis was performed through the Annexin V/PI test. Representative Annexin V vs. PI dot plots are shown. Q1, necrotic cells; Q2, late apoptosis cells; Q3, viable cells; Q4, early apoptosis cells. (B) The table shows the percentage of cells in each quadrant, representing the mean \pm S.E.M. of three different experiments. ${ }^{* *} P<0.01$ vs. control; ${ }^{\wedge} P<0.05$ and ${ }^{\wedge} P<0.01$ vs. $6-\mathrm{OHDA} ;{ }^{\circ} P<0.05$ vs. $6-\mathrm{OHDA}+\mathrm{BJ} 0.5 \%$. (C) Data of caspase-3 activity are presented as the mean of three experiments \pm S.E.M. ${ }^{\circ \circ \circ} P<0.001$ vs. control; $* * * P<0.001$ vs. 6-OHDA.

A

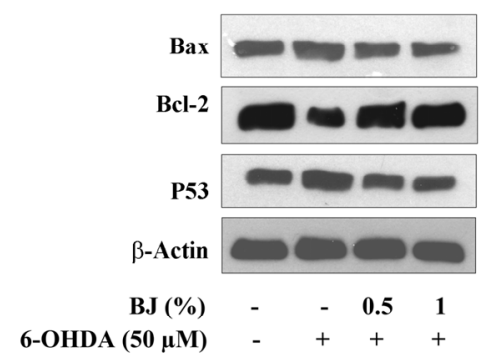

B

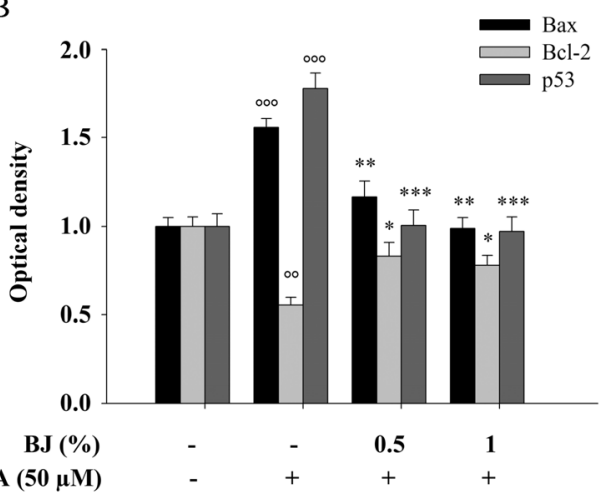

Figure 5. Protective effect of BJ on apoptotic-related proteins. SH-SY5Y cells were treated as reported above. Then, p53, Bax and Bcl-2 proteins levels were measured by western blotting. Representative immunoblots are displayed (A). Densitometric analysis of three independent blots (mean \pm SEM) is depicted (B). Proteins amount were extrapolated as the values found in the untreated cells which were arbitrarily expressed as $1 .{ }^{\circ} P<0.01$ and ${ }^{\circ \circ \circ} P<0.001$ vs. control cells; ${ }^{*}{ }^{* *}$ and ${ }^{* * *} P<0.05, P<0.01$ and $P<0.001$ vs. 6-OHDA-treated cells, respectively.

\subsection{Effect of BJ on 6-OHDA-Induced MAPKs Activation}

We further examined the involvement of p38 and extracellular signal-regulated 1 and 2 (ERK1/2), two mitogen-activated protein kinases (MAPKs), which are related to oxidative stress-induced cell death and survival. Figure 6 shows that incubation of differentiated SH-SY5Y cells with 6-OHDA $(50 \mu \mathrm{M})$ for $6 \mathrm{~h}$ enhanced the phosphorylation of both ERK1/2 and p38 (up to 2.2 and 3-fold versus control, respectively; $P<0.001$ ). Treatment with neuroprotective concentration of BJ prevented both 
p38 $(P<0.05$ and $P<0.01$ for BJ $0.5 \%$ and $1 \%$, respectively) and ERK1/2 $(P<0.01$ and $P<0.001$ for BJ $0.5 \%$ and $1 \%$, respectively) phosphorylation induced by 6-OHDA (Figure 6A, B), without affecting total levels of the inactive forms.

A

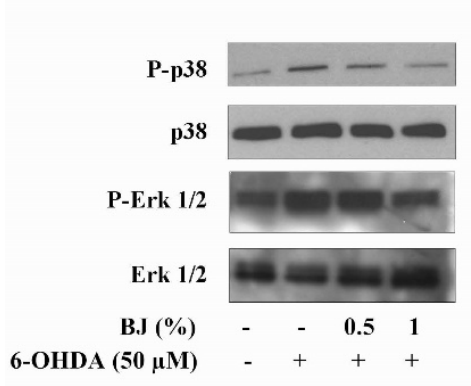

B

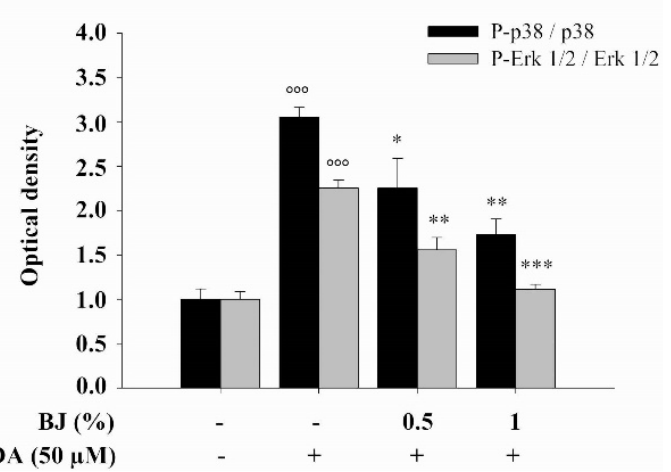

Figure 6. BJ reduces the phosphorylation of mitogen-activated protein kinases (MAPKs) induced by 6-OHDA. 6-OHDA induces the phosphorylation of Erk1/2 and p38 MAPKs in SH-SY5Y cells that was prevented by the pre-treatment with BJ. A representative immunoblot is depicted (A). The densitometric analysis of three separate blots (mean \pm S.E.M.) is showed (B). Protein levels are extrapolated as values detected in control cells, which are arbitrarily assigned as $1 .{ }^{\circ \circ \circ} P<0.001 \mathrm{vs.} \mathrm{control;}{ }^{*}$, ${ }^{*}$ and *** $P<0.05, P<0.01$ and $P<0.001$ vs. 6-OHDA-treated cells.

\subsection{BJ Reduces NF- $\kappa B$ Activation Elicited by 6-OHDA}

In order to better clarify the mechanism of neuroprotection exerted by BJ, we investigated whether BJ prevents the activation of the nuclear transcription factor- $\kappa \mathrm{B}(\mathrm{NF}-\mathrm{\kappa} \mathrm{B})$ by EMSA analysis. Cell treatment with 50- $\mu \mathrm{M}$ 6-OHDA elicited NF- $\mathrm{B}$ nuclear translocation within $6 \mathrm{~h}$ of exposure, while $1 \mathrm{~h}$ of pre-treatment with BJ prevented the activation of this nuclear factor. As shown in Figure 7 , both BJ concentrations were able to reduce the nuclear translocation of NF-kB evoked by 6-OHDA.

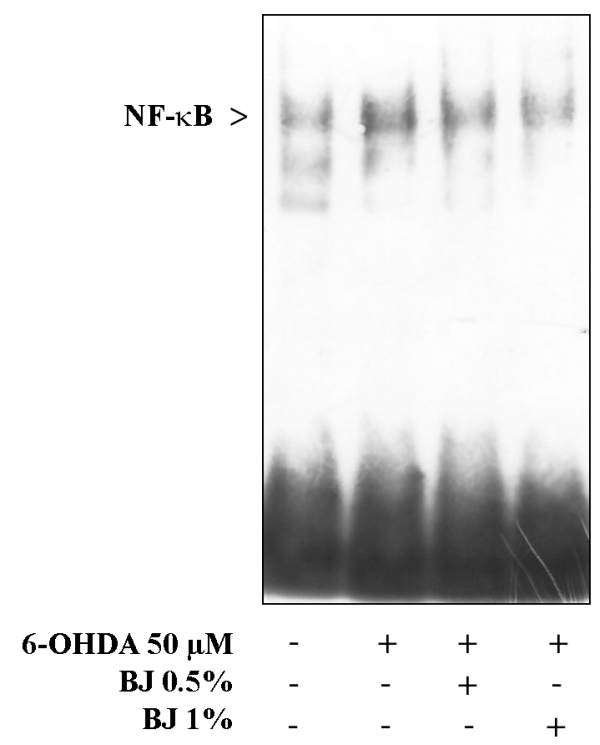

Figure 7. BJ reduces the activation of NF-kB induced by 6-OHDA. The gel electromobility shift assay (EMSA) analysis showing the nuclear translocation of NF-kB was performed after the exposure of differentiated cells to 6-OHDA subsequent to a pre-treatment with BJ. A representative image of two independent experiments is displayed. 


\subsection{BJ Reduces the Cellular Production of NO and the Levels of nNOS and iNOS}

Exposure of differentiated SH-SY5Y cells to 50- $\mu \mathrm{M}$ 6-OHDA for $24 \mathrm{~h}$ led to $50 \%$ increase of NO production $(P<0.01$; Figure $8 \mathrm{~A})$, that was prevented by $1 \mathrm{~h}$ of pre-treatment with $\mathrm{BJ}(P<0.05$ compared to 6-OHDA-treated cells; Figure $8 \mathrm{~A}$ ), while BJ alone at both $0.5 \%$ and $1 \%$ concentrations had no effect on NO production (data not shown). Data of western blot analysis strengthen these findings, showing that $\mathrm{BJ}$ at both tested concentrations reduced significantly the rise of both nNOS and iNOS expression caused by 6-OHDA ( $P<0.001$; Figure 8 B,C). These results indicate that the BJ-protective effect against 6-OHDA-induced SH-SY5Y cell death, at least in part, can occur preventing the rise of intracellular NO levels.

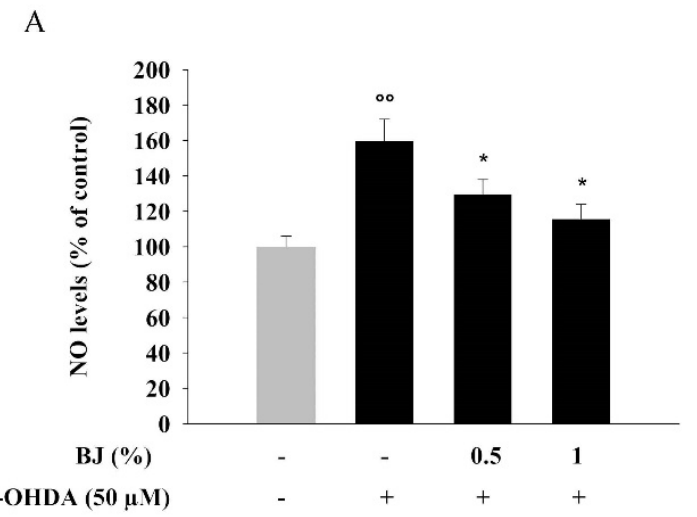

B

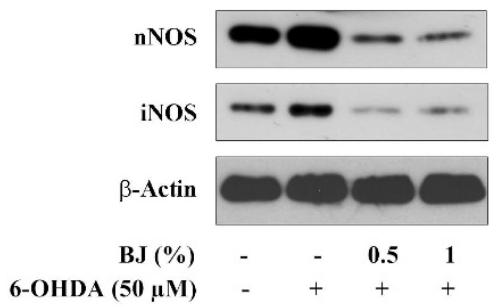

$\mathrm{C}$

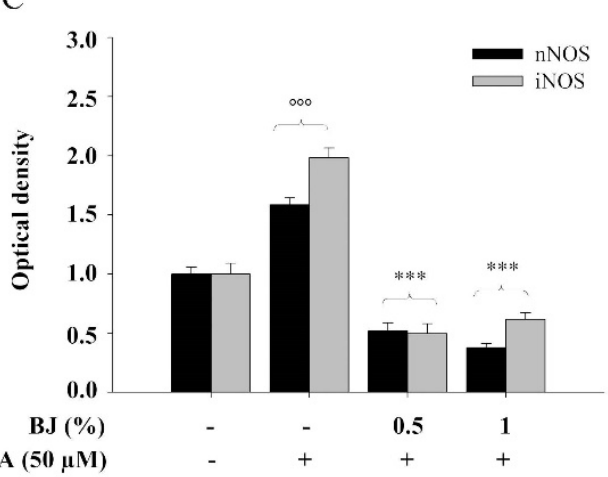

Figure 8. BJ prevents the 6-OHDA-induced NO release and reduces the expression of $\mathrm{nNOS}$ and iNOS. (A) Differences in NO production found in cells either or not pre-treated with BJ and then exposed to the 6-OHDA are reported as percentage of $\mathrm{NO}$ value detected in treated cells compared to those found in untreated ones. The levels of NO were measured by a colorimetric assay. Results are expressed as means \pm S.E.M. from three independent experiments. (B) Levels of nNOS and iNOS proteins from cell cultures treated as described above, were determined by western blot analyses. Representative immunoblots are shown. (C) Densitometric analysis of blots from three different experiments (mean \pm S.E.M.) is presented. ${ }^{\circ \circ} P<0.001$ and ${ }^{\circ \circ} P<0.01$ vs. control; ${ }^{*}$ and ${ }^{* * *} P<0.05$ and $P<0.001$ vs. 6-OHDA treated cells, respectively.

\section{Discussion}

This study, for the first time, shows the neuroprotective potentiality of BJ. We investigated the effect of this freshly squeezed Citrus juice against 6-OHDA-induced toxicity in differentiated human neuroblastoma SH-SY5Y cells, an experimental model extensively used to resemble PD in vitro [23].

Although neuropathological features of PD are well described, to date, the exact etiology of PD is not completely understood, whereas 6-OHDA may be considered one of the main responsible of its pathogenesis. Indeed, it has been detected in both brain and urine of PD patients [34] and it is capable to produce a toxicity similar to the neuropathological and biochemical characteristics of PD [23]. 
The 6-OHDA is a highly oxidizable dopamine analog that may be oxidized by molecular oxygen generating large amount of ROS, that in turn determine mitochondrial impairment, lipid peroxidation, DNA damage and cell death. Consistently, several studies suggest that increased ROS and mitochondrial impairment act in the pathogenesis of PD [18]. Therefore, novel pharmacological strategies based on antioxidant molecules are desirable, in order to reduce the progression of dopaminergic cell death observed in patients with PD and to obtain a better management of them.

Recently, we demonstrated that BJ, along with its flavonoid-rich extract (BJe), possesses antioxidant $[27,35]$ and anti-inflammatory [33,36-40] activities. We further demonstrated the antimicrobial effect of BJe [41], as well as its anti-cancer properties, both in vitro [24,25,42] and in vivo [26,43]. On the other hand, the beneficial effects of Citrus fruits and their juice against degenerative conditions are well-known [10,13,37,44-48].

In this paper, we first documented the antioxidant activity of BJ in cell-free assays and, afterwards, we demonstrated its ability to reduce ROS levels produced by both 6-OHDA and $\mathrm{H}_{2} \mathrm{O}_{2}$. Since 6-OHDA-induced ROS trigger mitochondrial membrane damage, resulting in the collapse of $\Delta \psi \mathrm{m}$, leading to apoptotic cell death [49], the blockage of ROS generation may represent an important intervention to protect neurons. The neuronal cell death can also be due to the overproduced $\mathrm{H}_{2} \mathrm{O}_{2}$, as occurring in pathological process of acute and chronic neuronal toxicity, including PD. The free radical-scavenging activity exerted by BJ can be responsible for the restoration of $\Delta \psi \mathrm{m}$, that we observed in the SH-SY5Y cultures pre-treated with the juice and then exposed to the two agents causing oxidative stress. Breaking this vicious circle, BJ protects the SH-SY5Y cells from the oxidative cell death triggered by either 6-OHDA or $\mathrm{H}_{2} \mathrm{O}_{2}$ that occurs by both apoptosis and necrosis.

Apoptosis is finely controlled by several factors, among which tumor suppressing and inducing genes, which could promote cell survival or induce apoptosis. It is known that high levels of ROS cause apoptosis, triggered by mitochondrial alterations and release of pro-apoptotic factors [50]. In turn, ROS accumulation may be the result of mitochondrial dysfunction and can be involved in cell death [51]. Moreover, ROS mediate intracellular signaling cascades and the activation of some apoptotic factors, such as proteins of the Bcl-2 family [18]. In this study, we demonstrated that BJ inhibits the activation of caspase-3 induced by 6-OHDA, as well as reduces the levels of the pro-apoptotic protein Bax, along with increasing those of the anti-apoptotic Bcl-2. On these bases, we can assume that, at least in part, BJ prevents the apoptosis elicited by 6-OHDA through the protection of mitochondria.

The MAPKs pathways have a prominent role in regulating cellular processes such as proliferation, differentiation and adaptation, and are involved in the pathogenesis of PD [52]. Once activated, ERK, JNK and p38 phosphorylate several transcription factors and cytosolic proteins, with a subsequent augmentation of their transcriptional activities and activation of dependent genes [52]. Moreover, it has been reported that MAPKs are necessary for 6-OHDA-induced apoptosis [53]. In accordance with previous reports, we observed that treatment with 6-OHDA increased phosphorylation of ERK1/2 and p38 in SH-SY5Y cells, confirming a link between ROS generation by 6-OHDA and initiation of MAPKs signaling. The pre-treatment of neuroblastoma cells with BJ reduced the ERK1/2 and p38 phosphorylation, indicating that the neuroprotective effects of BJ against 6-OHDA toxicity is related to the modulation of MAPKs pathways.

One target of activated MAPKs is the nuclear transcription factor NF-kB which, from the inactive state in the cytosol, following phosphorylation of its inhibitory subunits, translocates into the nucleus, where acts as a transcriptional regulator of other proteins. It has been reported that the activation of NF-kB is involved in the pathogenesis of several neurodegenerative disorders and increased in dopaminergic neurons of PD patients [54]. Several in vitro studies reported that the activation of NF-kB plays a pivotal role in 6-OHDA induced cell death. Authors reported that some pharmacological agents possess neuroprotective effect due to their ability to block NF- $\mathrm{KB}$ activation, suggesting its pro-apoptotic role in PD [55-57], thus being a possible target to counteract neurodegenerative diseases. In this regard, we investigated the effects of BJ on NF-kB activation induced by 6-OHDA, and we found that BJ prevented the NF-kB activation by inhibiting its nuclear translocation. Once activated, 
NF- $\mathrm{kB}$ increases the expression of different genes implied in either cell death or survival, including p53 and c-Myc [58]. P53 is implied in apoptotic death of dopaminergic neurons, and its increased expression has also been reported in cellular model of PD [59]. In addition, p53 is a positive transcriptional activator for Bax and a negative one for Bcl-2 and Bcl-XL [60]. In our study, western blot analysis displayed that p53 increased significantly in cells treated with 6-OHDA and the levels were restored by the pre-treatment with $\mathrm{BJ}$, suggesting that both NF- $\mathrm{kB}$ and $\mathrm{p} 53$ take part the mechanism through which BJ acts against 6-OHDA injury.

Nitric oxide (NO) is a signaling molecule in the biologic system which is thought to be also a neurotoxin. In this regard, its excessive production in brain causes both neuronal damage and death. It has been demonstrated that NO is implicated in the pathogenesis of neurodegenerative diseases, including PD [61]. There are three known isoforms of nitric oxide synthase (NOS) in the mammals: neuronal NOS (nNOS), inducible NOS (iNOS) and endothelial NOS (eNOS). Each isoform is recognized to be strictly related to the pathogenesis of PD. Here, we reported that the expression of nNOS and iNOS enhanced after the treatment of differentiated SH-SY5Y with 6-OHDA, as well as increased the production of NO. Of note, BJ decreased the release of NO and both nNOS and iNOS protein levels. Considering that iNOS is a downstream target of NF- $\mathrm{kB}$, the changes in iNOS levels observed in this study could be derived from the reduced activity of NF-kB induced by BJ.

\section{Conclusions}

To summarize the results of our in vitro study, we showed that BJ markedly inhibited 6-OHDA-induced apoptosis in differentiated human neuroblastoma SH-SY5Y cells, through mitigating the ROS and NO generation, the mitochondrial dysfunctions and the imbalance of Bcl-2 family proteins, as well as reducing the activation of MAPKs and the nuclear translocation of NF-kB. To the best of our knowledge, this is the first report showing the neuroprotective effect of BJ, exerted by mechanisms involving the interplay with specific cell targets and its antioxidant activity, making it worthy of consideration in the field of neurodegenerative diseases.

Author Contributions: N.F. performed the experiments and helped in writing the manuscript; S.C. performed the experiments; A.M., C.R. and G.E.L. supported the experimental procedures; S.G. assisted in the interpretation of the data; G.C. critically revised the manuscript; V.M. critically revised the manuscript; M.N. conceived and designed the experiments as well as drafted the manuscript. All authors have read and agreed to the published version of the manuscript.

Funding: Research was supported by Grant from Sicily Region (PO FESR Sicilia 2007/2013, CUP G73F11000050004 to $\mathrm{MN}$, project "MEPRA", $\mathrm{n}^{\circ} 133$ of Linea d'Intervento 4.1.1.1).

Acknowledgments: A fellowship from the "Prof. Antonio Imbesi" Foundation, Messina, Italy to CR and a fellowship from the "NUTRAMED 04" research project, University "Magna Græcia" of Catanzaro, Italy to NF, are gratefully acknowledged.

Conflicts of Interest: The authors declare no conflict of interest.

\section{References}

1. Puspita, L.; Chung, S.Y.; Shim, J.W. Oxidative stress and cellular pathologies in Parkinson's disease. Mol. Brain 2017, 10, 53. [CrossRef] [PubMed]

2. Trist, B.G.; Hare, D.J.; Double, K.L. Oxidative stress in the aging substantia nigra and the etiology of Parkinson's disease. Aging Cell 2019, 18, e13031. [CrossRef] [PubMed]

3. Poewe, W.; Seppi, K.; Tanner, C.M.; Halliday, G.M.; Brundin, P.; Volkmann, J.; Schrag, A.E.; Lang, A.E. Parkinson disease. Nat. Rev. Dis. Primers 2017, 3, 17013. [CrossRef] [PubMed]

4. Ciulla, M.; Marinelli, L.; Cacciatore, I.; Stefano, A.D. Role of Dietary Supplements in the Management of Parkinson's Disease. Biomolecules 2019, 9, 271. [CrossRef] [PubMed]

5. Li, J.; Long, X.; Hu, J.; Bi, J.; Zhou, T.; Guo, X.; Han, C.; Huang, J.; Wang, T.; Xiong, N.; et al. Multiple pathways for natural product treatment of Parkinson's disease: A mini review. Phytomedicine 2019, 60, 152954. [CrossRef] [PubMed] 
6. Hang, L.; Basil, A.H.; Lim, K.L. Nutraceuticals in Parkinson's Disease. Neuromol. Med. 2016, 18, 306-321. [CrossRef]

7. Cirmi, S.; Ferlazzo, N.; Lombardo, G.E.; Ventura-Spagnolo, E.; Gangemi, S.; Calapai, G.; Navarra, M. Neurodegenerative Diseases: Might Citrus Flavonoids Play a Protective Role? Molecules 2016, 21, 1312. [CrossRef]

8. Navarra, M.; Mannucci, C.; Delbo, M.; Calapai, G. Citrus bergamia essential oil: From basic research to clinical application. Front. Pharmacol. 2015, 6, 36. [CrossRef]

9. Mannucci, C.; Navarra, M.; Calapai, F.; Squeri, R.; Gangemi, S.; Calapai, G. Clinical Pharmacology of Citrus bergamia: A Systematic Review. Phytother. Res. 2017, 31, 27-39. [CrossRef]

10. Cirmi, S.; Bisignano, C.; Mandalari, G.; Navarra, M. Anti-infective potential of Citrus bergamia Risso et Poiteau (bergamot) derivatives: A systematic review. Phytother. Res. 2016, 30, 1404-1411. [CrossRef]

11. Navarra, M.; Ferlazzo, N.; Cirmi, S.; Trapasso, E.; Bramanti, P.; Lombardo, G.E.; Minciullo, P.L.; Calapai, G.; Gangemi, S. Effects of bergamot essential oil and its extractive fractions on SH-SY5Y human neuroblastoma cell growth. J. Pharm. Pharmacol. 2015, 67, 1042-1053. [CrossRef] [PubMed]

12. Corasaniti, M.T.; Maiuolo, J.; Maida, S.; Fratto, V.; Navarra, M.; Russo, R.; Amantea, D.; Morrone, L.A.; Bagetta, G. Cell signaling pathways in the mechanisms of neuroprotection afforded by bergamot essential oil against NMDA-induced cell death in vitro. Br. J. Pharmacol. 2007, 151, 518-529. [CrossRef] [PubMed]

13. Ferlazzo, N.; Cirmi, S.; Calapai, G.; Ventura-Spagnolo, E.; Gangemi, S.; Navarra, M. Anti-Inflammatory Activity of Citrus bergamia Derivatives: Where Do We Stand? Molecules 2016, 21, 1273. [CrossRef] [PubMed]

14. Mollace, V.; Scicchitano, M.; Paone, S.; Casale, F.; Calandruccio, C.; Gliozzi, M.; Musolino, V.; Carresi, C.; Maiuolo, J.; Nucera, S.; et al. Hypoglycemic and Hypolipemic Effects of a New Lecithin Formulation of Bergamot Polyphenolic Fraction: A Double Blind, Randomized, Placebo- Controlled Study. Endocr. Metab. Immune Disord. Drug Targets 2019, 19, 136-143. [CrossRef] [PubMed]

15. Huang, D.J.; Ou, B.X.; Prior, R.L. The chemistry behind antioxidant capacity assays. J. Agric. Food Chem. 2005, 53, 1841-1856. [CrossRef]

16. Cirmi, S.; Ferlazzo, N.; Lombardo, G.E.; Maugeri, A.; Calapai, G.; Gangemi, S.; Navarra, M. Chemopreventive Agents and Inhibitors of Cancer Hallmarks: May Citrus Offer New Perspectives? Nutrients 2016, 8, 698. [CrossRef]

17. Musumeci, L.; Maugeri, A.; Cirmi, S.; Lombardo, G.E.; Russo, C.; Gangemi, S.; Calapai, G.; Navarra, M. Citrus fruits and their flavonoids in inflammatory bowel disease: An overview. Nat. Prod. Res. 2020, 34, 122-136. [CrossRef]

18. Guo, J.D.; Zhao, X.; Li, Y.; Li, G.R.; Liu, X.L. Damage to dopaminergic neurons by oxidative stress in Parkinson's disease (Review). Int. J. Mol. Med. 2018, 41, 1817-1825. [CrossRef]

19. Cirmi, S.; Ferlazzo, N.; Gugliandolo, A.; Musumeci, L.; Mazzon, E.; Bramanti, A.; Navarra, M. Moringin from Moringa Oleifera Seeds Inhibits Growth, Arrests Cell-Cycle, and Induces Apoptosis of SH-SY5Y Human Neuroblastoma Cells through the Modulation of NF-kappaB and Apoptotic Related Factors. Int. J. Mol. Sci. 2019, 20, 1980. [CrossRef]

20. Maher, P. The Potential of Flavonoids for the Treatment of Neurodegenerative Diseases. Int. J. Mol. Sci. 2019, 20, 3056. [CrossRef]

21. Maugeri, A.; Cirmi, S.; Minciullo, P.L.; Gangemi, S.; Calapai, G.; Mollace, V.; Navarra, M. Citrus fruits and inflammaging: A systematic review. Phytochem. Rev. 2019, 18, 1025-1049. [CrossRef]

22. Yang, Y.; Bai, L.; Li, X.; Xiong, J.; Xu, P.; Guo, C.; Xue, M. Transport of active flavonoids, based on cytotoxicity and lipophilicity: An evaluation using the blood-brain barrier cell and Caco-2 cell models. Toxicol. In Vitro 2014, 28, 388-396. [CrossRef] [PubMed]

23. Xicoy, H.; Wieringa, B.; Martens, G.J. The SH-SY5Y cell line in Parkinson's disease research: A systematic review. Mol. Neurodegener. 2017, 12, 10. [CrossRef] [PubMed]

24. Delle Monache, S.; Sanita, P.; Trapasso, E.; Ursino, M.R.; Dugo, P.; Russo, M.; Ferlazzo, N.; Calapai, G.; Angelucci, A.; Navarra, M. Mechanisms underlying the anti-tumoral effects of Citrus Bergamia juice. PLoS ONE 2013, 8, e61484. [CrossRef] [PubMed]

25. Ferlazzo, N.; Cirmi, S.; Russo, M.; Trapasso, E.; Ursino, M.R.; Lombardo, G.E.; Gangemi, S.; Calapai, G.; Navarra, M. NF- $\mathrm{kB}$ mediates the antiproliferative and proapoptotic effects of bergamot juice in HepG2 cells. Life Sci. 2016, 146, 81-91. [CrossRef] [PubMed] 
26. Navarra, M.; Ursino, M.R.; Ferlazzo, N.; Russo, M.; Schumacher, U.; Valentiner, U. Effect of Citrus bergamia juice on human neuroblastoma cells in vitro and in metastatic xenograft models. Fitoterapia 2014, 95, 83-92. [CrossRef]

27. Ferlazzo, N.; Visalli, G.; Smeriglio, A.; Cirmi, S.; Lombardo, G.E.; Campiglia, P.; di Pietro, A.; Navarra, M. Flavonoid Fraction of Orange and Bergamot Juices Protect Human Lung Epithelial Cells from Hydrogen Peroxide-Induced Oxidative Stress. Evid. Based Complement. Alternat. Med. 2015, 2015, 957031. [CrossRef]

28. Condello, S.; Calabro, E.; Caccamo, D.; Curro, M.; Ferlazzo, N.; Satriano, J.; Magazu, S.; Ientile, R. Protective effects of agmatine in rotenone-induced damage of human SH-SY5Y neuroblastoma cells: Fourier transform infrared spectroscopy analysis in a model of Parkinson's disease. Amino Acids 2012, 42, 775-781. [CrossRef]

29. Morisi, R.; Celano, M.; Tosi, E.; Schenone, S.; Navarra, M.; Ferretti, E.; Costante, G.; Durante, C.; Botta, G.; D'Agostino, M.; et al. Growth inhibition of medullary thyroid carcinoma cells by pyrazolo-pyrimidine derivates. J. Endocrinol. Investig. 2007, 30, RC31-RC34. [CrossRef]

30. Corasaniti, M.T.; Bilotta, A.; Strongoli, M.C.; Navarra, M.; Bagetta, G.; di Renzo, G. HIV-1 coat protein gp120 stimulates interleukin- $1 \beta$ secretion from human neuroblastoma cells: Evidence for a role in the mechanism of cell death. Br. J. Pharmacol. 2001, 134, 1344-1350. [CrossRef]

31. Corasaniti, M.T.; Navarra, M.; Catani, M.V.; Melino, G.; Nistico, G.; Finazzi-Agro, A. NMDA and HIV-1 coat protein, GP120, produce necrotic but not apoptotic cell death in human CHP100 neuroblastoma cultures via a mechanism involving calpain. Biochem. Biophys. Res. Commun. 1996, 229, 299-304. [CrossRef] [PubMed]

32. Celano, M.; Maggisano, V.; de Rose, R.F.; Bulotta, S.; Maiuolo, J.; Navarra, M.; Russo, D. Flavonoid Fraction of Citrus reticulata Juice Reduces Proliferation and Migration of Anaplastic Thyroid Carcinoma Cells. Nutr. Cancer 2015, 67, 1183-1190. [CrossRef] [PubMed]

33. Risitano, R.; Curro, M.; Cirmi, S.; Ferlazzo, N.; Campiglia, P.; Caccamo, D.; Ientile, R.; Navarra, M. Flavonoid fraction of Bergamot juice reduces LPS-induced inflammatory response through SIRT1-mediated NF- $\mathrm{B}$ inhibition in THP-1 monocytes. PLoS ONE 2014, 9, e107431. [CrossRef] [PubMed]

34. Andrew, R.; Watson, D.G.; Best, S.A.; Midgley, J.M.; Wenlong, H.; Petty, R.K. The determination of hydroxydopamines and other trace amines in the urine of parkinsonian patients and normal controls. Neurochem. Res. 1993, 18, 1175-1177. [CrossRef]

35. Ferlazzo, N.; Visalli, G.; Cirmi, S.; Lombardo, G.E.; Lagana, P.; di Pietro, A.; Navarra, M. Natural iron chelators: Protective role in A549 cells of flavonoids-rich extracts of Citrus juices in $\mathrm{Fe}^{3+}$-induced oxidative stress. Environ. Toxicol. Pharmacol. 2016, 43, 248-256. [CrossRef]

36. Curro, M.; Risitano, R.; Ferlazzo, N.; Cirmi, S.; Gangemi, C.; Caccamo, D.; Ientile, R.; Navarra, M. Citrus bergamia Juice Extract Attenuates $\beta$-Amyloid-Induced Pro-Inflammatory Activation of THP-1 Cells Through MAPK and AP-1 Pathways. Sci. Rep. 2016, 6, 20809. [CrossRef]

37. Maugeri, A.; Ferlazzo, N.; de Luca, L.; Gitto, R.; Navarra, M. The link between the AMPK/SIRT1 axis and a flavonoid-rich extract of Citrus bergamia juice: A cell-free, in silico, and in vitro study. Phytother. Res. 2019, 33, 1805-1814. [CrossRef]

38. Gugliandolo, E.; Fusco, R.; D'Amico, R.; Peditto, M.; Oteri, G.; di Paola, R.; Cuzzocrea, S.; Navarra, M. Treatment with a Flavonoid-Rich Fraction of Bergamot Juice Improved Lipopolysaccharide-Induced Periodontitis in Rats. Front. Pharmacol. 2018, 9, 1563. [CrossRef]

39. Impellizzeri, D.; Bruschetta, G.; di Paola, R.; Ahmad, A.; Campolo, M.; Cuzzocrea, S.; Esposito, E.; Navarra, M. The anti-inflammatory and antioxidant effects of bergamot juice extract (BJe) in an experimental model of inflammatory bowel disease. Clin. Nutr. 2015, 34, 1146-1154. [CrossRef]

40. Impellizzeri, D.; Cordaro, M.; Campolo, M.; Gugliandolo, E.; Esposito, E.; Benedetto, F.; Cuzzocrea, S.; Navarra, M. Anti-inflammatory and Antioxidant Effects of Flavonoid-Rich Fraction of Bergamot Juice (BJe) in a Mouse Model of Intestinal Ischemia/Reperfusion Injury. Front. Pharmacol. 2016, 7, 203. [CrossRef]

41. Filocamo, A.; Bisignano, C.; Mandalari, G.; Navarra, M. In Vitro Antimicrobial Activity and Effect on Biofilm Production of a White Grape Juice (Vitis vinifera) Extract. Evid. Based Complement. Alternat. Med. 2015, 2015, 856243. [CrossRef] [PubMed]

42. Visalli, G.; Ferlazzo, N.; Cirmi, S.; Campiglia, P.; Gangemi, S.; di Pietro, A.; Calapai, G.; Navarra, M. Bergamot juice extract inhibits proliferation by inducing apoptosis in human colon cancer cells. Anticancer Agents Med. Chem. 2014, 14, 1402-1413. [CrossRef] [PubMed] 
43. Navarra, M.; Femia, A.P.; Romagnoli, A.; Tortora, K.; Luceri, C.; Cirmi, S.; Ferlazzo, N.; Caderni, G. A flavonoid-rich extract from bergamot juice prevents carcinogenesis in a genetic model of colorectal cancer, the Pirc rat (F344/NTac-Apc(am1137)). Eur. J. Nutr. 2019, 58, 885-894. [CrossRef] [PubMed]

44. Cirmi, S.; Navarra, M.; Woodside, J.V.; Cantwell, M.M. Citrus fruits intake and oral cancer risk: A systematic review and meta-analysis. Pharmacol. Res. 2018, 133, 187-194. [CrossRef]

45. Mulvihill, E.E.; Burke, A.C.; Huff, M.W. Citrus Flavonoids as Regulators of Lipoprotein Metabolism and Atherosclerosis. Annu. Rev. Nutr. 2016, 36, 275-299. [CrossRef]

46. Cirmi, S.; Maugeri, A.; Ferlazzo, N.; Gangemi, S.; Calapai, G.; Schumacher, U.; Navarra, M. Anticancer Potential of Citrus Juices and Their Extracts: A Systematic Review of Both Preclinical and Clinical Studies. Front. Pharmacol. 2017, 8, 420. [CrossRef]

47. Jaganathan, S.K.; Vellayappan, M.V.; Narasimhan, G.; Supriyanto, E. Role of pomegranate and citrus fruit juices in colon cancer prevention. World J. Gastroenterol. 2014, 20, 4618-4625. [CrossRef]

48. Fusco, R.; Cirmi, S.; Gugliandolo, E.; di Paola, R.; Cuzzocrea, S.; Navarra, M. A flavonoid-rich extract of orange juice reduced oxidative stress in an experimental model of inflammatory bowel disease. J. Funct. Foods 2017, 30, 168-178. [CrossRef]

49. Guo, S.; Bezard, E.; Zhao, B. Protective effect of green tea polyphenols on the SH-SY5Y cells against 6-OHDA induced apoptosis through ROS-NO pathway. Free Radic. Biol. Med. 2005, 39, 682-695. [CrossRef]

50. Redza-Dutordoir, M.; Averill-Bates, D.A. Activation of apoptosis signalling pathways by reactive oxygen species. Biochim. Biophys. Acta 2016, 1863, 2977-2992. [CrossRef]

51. Elfawy, H.A.; Das, B. Crosstalk between mitochondrial dysfunction, oxidative stress, and age related neurodegenerative disease: Etiologies and therapeutic strategies. Life Sci. 2019, 218, 165-184. [CrossRef] [PubMed]

52. Bohush, A.; Niewiadomska, G.; Filipek, A. Role of Mitogen Activated Protein Kinase Signaling in Parkinson's Disease. Int. J. Mol. Sci. 2018, 19, 2973. [CrossRef] [PubMed]

53. Rai, S.N.; Dilnashin, H.; Birla, H.; Singh, S.S.; Zahra, W.; Rathore, A.S.; Singh, B.K.; Singh, S.P. The Role of PI3K/Akt and ERK in Neurodegenerative Disorders. Neurotox Res. 2019, 35, 775-795. [CrossRef] [PubMed]

54. Sivandzade, F.; Prasad, S.; Bhalerao, A.; Cucullo, L. NRF2 and NF-B interplay in cerebrovascular and neurodegenerative disorders: Molecular mechanisms and possible therapeutic approaches. Redox Biol. 2019, 21, 101059. [CrossRef] [PubMed]

55. Cui, C.; Cui, N.; Wang, P.; Song, S.; Liang, H.; Ji, A. Neuroprotective effect of sulfated polysaccharide isolated from sea cucumber Stichopus japonicus on 6-OHDA-induced death in SH-SY5Y through inhibition of MAPK and NF-KB and activation of PI3K/Akt signaling pathways. Biochem. Biophys. Res. Commun. 2016, 470, 375-383. [CrossRef] [PubMed]

56. Dong, H.; Li, R.; Yu, C.; Xu, T.; Zhang, X.; Dong, M. Paeoniflorin inhibition of 6-hydroxydopamine-induced apoptosis in PC12 cells via suppressing reactive oxygen species-mediated $\mathrm{PKC} \delta / \mathrm{NF}-\mathrm{\kappa B}$ pathway. Neuroscience 2015, 285, 70-80. [CrossRef] [PubMed]

57. Park, J.H.; Seo, Y.H.; Jang, J.H.; Jeong, C.H.; Lee, S.; Park, B. Asiatic acid attenuates methamphetamine-induced neuroinflammation and neurotoxicity through blocking of NF-kB/STAT3/ERK and mitochondria-mediated apoptosis pathway. J. Neuroinflammation. 2017, 14, 240. [CrossRef]

58. Albensi, B.C. What Is Nuclear Factor Kappa B (NF-кB) Doing in and to the Mitochondrion? Front. Cell Dev. Biol. 2019, 7, 154. [CrossRef]

59. Dai, C.Q.; Luo, T.T.; Luo, S.C.; Wang, J.Q.; Wang, S.M.; Bai, Y.H.; Yang, Y.L.; Wang, Y.Y. p53 and mitochondrial dysfunction: Novel insight of neurodegenerative diseases. J. Bioenerg. Biomembr. 2016, 48, 337-347. [CrossRef]

60. Chi, S.W. Structural insights into the transcription-independent apoptotic pathway of p53. BMB Rep. 2014, 47, 167-172. [CrossRef]

61. Dawson, T.M.; Dawson, V.L. Nitric Oxide Signaling in Neurodegeneration and Cell Death. Adv. Pharmacol. 2018, 82, 57-83. [PubMed]

(C) 2020 by the authors. Licensee MDPI, Basel, Switzerland. This article is an open access article distributed under the terms and conditions of the Creative Commons Attribution (CC BY) license (http://creativecommons.org/licenses/by/4.0/). 